\title{
Transfer to Processing Tomato and Characterization of Late Blight Resistance Derived from Solanum pimpinellifolium L. L3708
}

\author{
Min-Jea Kim ${ }^{1}$ and Martha A. Mutschler ${ }^{2}$ \\ Department of Plant Breeding, Cornell University, 303 Bradfield Hall, Ithaca, NY 14853
}

\begin{abstract}
AdDitional INDEX WORDs. disease resistance, Phytophthora infestans, Lycopersicon esculentum, dominance
Aвstract. Late blight [caused by Phytophthora infestans (Mont.) de Bary] causes severe loss of tomato [Solanum lycopersicum L. (formerly Lycopersicon esculentum Mill.)] production in environments favorable to the pathogen. Researchers at the Asia Vegetable Research Development Center (AVRDC) identified resistance to late blight in an accession of $S$. pimpinellifolium [formerly $L$. pimpinellifolium $(\mathrm{L}$.) Mill.] that they named accession L3708. This resistance has now been transferred to processing tomato lines, which are resistant to multiple $P$. infestans isolates. Lab trials, inoculated field trials in New York, and naturally infested field trials in Mexico all indicate that these processing tomato lines are fixed for late blight resistance. Segregation data obtained for resistance in the breeding populations were dependent on the pathogen isolate used for the disease screen. Segregation data do not support the hypothesis of single gene control of the full resistance trait, but instead suggest that more than one gene is involved, and that these genes interact in an epistatic manner.
\end{abstract}

Late blight results in severe loss of tomato production when environment is favorable to the pathogen and disease development. As a result, late blight is ranked as one of the most important diseases in tomato (Garelik, 2002; Judelson, 1997; Umaerus and Umaerus, 1994). Within the United States, late blight ranked as the eighth most important tomato disease, based on a weighted average of loss per unit area (Davis et al., 1998). Late blight is currently controlled in tomato by the use of fungicidal sprays; the timing of these sprays in some regions is guided by blight forecasts based upon weather conditions (Davis et al., 1996, 1998; Raposo et al., 1993). However, despite the use of monitoring and controlling chemicals, losses in tomato due to late blight can be substantial. Furthermore, the use of sprays for control of this disease is increasingly difficult due to changes in pathogen virulence and increased chemical resistance of pathogen (Fry and Goodwin, 1997a, 1997b; Goodwin et al., 1998; Kato et al., 1997).

Attempts to breed late blight resistant tomato lines started $\approx 50$ years ago (Richards and Barratt, 1946), ultimately resulting in the identification of two tomato resistance genes, $P h-1$ and $P h-2$ (Gallegly, 1960; Peirce, 1970, 1971). $P h-l$ is a single dominant race-specific resistance gene derived from $S$. pimpinellifolium, which protects against race-O of the pathogen (Bonde and Murphy, 1952). The resistance of $P h-l$ was rapidly overcome due to the race specificity of this resistance gene (Conover and Walter, 1952, 1953; Gallegly, 1952). Ph-1 is included in the old fresh-

Received for publication 25 Jan. 2005. Accepted for publication 26 June 2005. We thank Drs. Peter Hanson and Lowell Black for generously sharing the resistance source L3708. We thank Dr. Randy Gardner for his donation of the initial resistant cuttings and seed for the fresh market $\mathrm{BC}_{1} \mathrm{~F}_{2}$ populations and for establishing the field trial in $\mathrm{NC}$, as well as discussion over the course of this work. We also thank Dr. William Fry for the Phytophthora infestans isolates he provided and for his advice on their culture. We thank Dr. Ira Stein of Campbell Soup Co. and Dr. Casey Garvey of ConAgra Foods, as well as their companies, for performing the field trials in California and Mexico. We also thank Dr. Tom Zitter for review and comments regarding this paper. This project was supported by gift funds from the California League of Food Processors and from USDA HATCH Project No. 149484.

'Current address: Division of Environmental and Life Sciences, Seoul Women's Univ., Seoul 139-774, Korea

2To whom reprint requests should be addressed.E-mail address: mam13@ cornell. edu market tomato cultivar, 'New Yorker', and in the old processing tomato cultivar, 'Nova'.

$P h-2$ is a single incompletely dominant gene also derived from S. pimpinellifolium. $P h-2$ does not affect a number of $P$. infestans isolates, and provides incomplete resistance against the $P$. infestans isolates it does affect (Goodwin et al., 1995). The degree of disease suppression by $P h-2$ is affected by additional factors (Laterrot, 1975; Turkensteen, 1973). Reported to contain $P h-2$ are the cultivars West Virginia 63, Legend, Centennial, Caline, Macline, Pieraline, Heline, Fline, Piline, Pieralbo, Heinz 1706, Campbell 28, Flora Dade, Earlymech, and Europeel (Gallegly, 1960; Laterrot, 1994). Therefore, there were no tomato cultivars with usable resistance to recent isolates of late blight.

Researchers at the AVRDC identified a new source of resistance in an S. pimpinellifolium accession L3708 (Asian Vegetable Research and Development Center, 1994), which they generously provided to other breeding programs. In later work with this resistance, they observed segregation for a single gene, $P h-3$, which they mapped to bottom of chromosome 9 (Chunwongse et al., 2002). The goal of the work reported here was 2-fold: to rapidly transfer the resistance in L3708 to commercial quality processing tomato line, and, in the process, collect additional information regarding the genetic control and nature of this resistance to facilitate future use of this resistance in elite tomato lines and hybrid cultivars.

\section{Materials and Methods}

Source of Late blight RESistance. The ultimate source of the late blight resistance used was S. pimpinellifolium accession L3708 (also known as LA1269, C.M. Rick Tomato Genetics Resource Center, Davis, Calif.; USDA accession NSL116890, and PI365957). However, R. Gardner of North Carolina State Univ. had already started the transfer of late blight resistance from L3708 to fresh-market tomato, and provided us with cuttings of five blight-resistant selections from a $\mathrm{BC}_{1} \mathrm{~F}_{2}$ population [NC215E x (NC215E x S. pimpinellifolium accession L3708)]. These cuttings were rooted, and the resulting clonally produced plants were used as pollen donors to pollinate processing to- 
matoes. This approach saved the time required to create and to screen the initial $\mathrm{F}_{1}, \mathrm{BC}_{1} \mathrm{~F}_{1}$, and $\mathrm{BC}_{1} \mathrm{~F}_{2}$ generations for transfer of late blight resistance.

Processing tomato backCross Parents uSED. Multiple female parents with different characteristics were used to provide genetic variability for horticultural characteristics in the breeding program. The processing tomatoes used for the first backcross to processor were 'Heinz 8892' (Heinzseed, Stockton Calif.), 'Rogers 1108' (ROGERS Brand Vegetable Seeds, Boise, Idaho), and 'Orsetti 3155' (Orsetti Seed Co., Hollister, Calif.), which are commercial hybrids that are VFFMi [possessing the resistance genes against verticillium (Verticillium dahliae Kleb) race 1, fusarium [Fusarium oxysporum Schlect. emend. f.sp. lycopersici (Sacc.) Snyd. and Hans.] race 1 and 2, and root knot nematode [Meloidogyne incognita (Kofoid \& White) Chitwood], respectively]. The second backcross females were either 'Hypeel 303' or 'Hypeel 45' (Seminis, Oxnard, Calif.), which were also commercial hybrids and are VFFMiPto [possessing the resistance genes against the diseases listed above plus bacterial speck (Pseudomonas syringae van Hall pv. tomato Okabe)].

DESIGNATION OF BACKCROSS GENERATIONS IN TOMATO POPULATIONS. Due to the use of fresh-market $\mathrm{BC}_{1} \mathrm{~F}_{2}$ selections as the source of resistance, a method was needed for designating the backcross generations in the processing tomato populations subsequently produced in this project. To avoid confusion, backcross numbers used below to describe the processing tomato populations produced refer only to additional backcrosses made to processing tomato. Therefore, the first backcross to processing tomato was described as a $\mathrm{BC}_{1} \mathrm{~F}_{1}$, not $\mathrm{BC}_{2} \mathrm{~F}_{1}$, even though the population has a total of two backcrosses to $S$. lycopersicum.

Phytophthora infestans isolates USED. The P. infestans isolates US-17 (Fry Lab No. 970001) and US-7 (Fry Lab No. 940486 and 940330) were obtained from W. Fry (Dept. of Plant Pathology, Cornell Univ.). These two isolates were chosen due to the high levels of disease they caused on tomato in prior field and lab assays, and since we knew that these isolates overcome the resistance of $\mathrm{Ph}-2$. US-7 was a dominant isolate throughout the United States, but has largely been replaced by newer isolates. US-17 is a more recent isolate that is found in the southeastern United States up the east coast to New Jersey and New York (Fry and Goodwin, 1997).

The original US-7 isolate (Fry Lab No. 940486) was used through 1998, but had lost pathogenicity by 1999. Therefore, another US-7 isolate (Fry Lab No. 940330) was used starting in 1999. These two isolates were both classified as being US-7 based upon RG57 fingerprinting. However, our work indicates that the initial pathogenicity of the 940330 isolate of US-7 is different than that of the 940486 isolate. Therefore, these two isolates are treated as unique, rather than the same isolate.

Phytophthora infestans CUlture, MaintenanCe, AND INOCULUM PREPARATION. Phytophthora infestans isolates were sub cultured every month on ryeB (Caten and Jinks, 1968) and pea media (Goodwin et al., 1994) for maintenance. Sporangia were isolated from culture plates with $\mathrm{ddH}_{2} \mathrm{O}$ and concentrated with brief centrifugation, and used to inoculate leaflets of the susceptible tomato genotype ' $V F T$ Vendor' to increase sporangia numbers and maintain pathogenicity, which might weaken during longterm culture. The 'VFT Vendor' plants used for this purpose were grown in a clean greenhouse without the use of any chemical controls. The leaflets were placed adaxial surface down on the lids of water agar plates, inoculated with sporangia suspension, and then covered by water agar containing petri dish bottoms.
The plates were incubated upside down at $18{ }^{\circ} \mathrm{C}$ and $16-\mathrm{h}$ light condition for 6-7 d. Production of sporangia was confirmed by examining leaflets under microscope $(100 \times)$.

This method was also used to increase sporangia for preparing inoculum for the disease screens by substantially increasing the number of 'VFT Vendor' leaflets inoculated and cultured. Sporangia produced on 'VFT Vendor' tomato leaflets were adjusted to the desired concentrations in the final inoculum suspension (sporangia per milliliter).

SCREENING METHODS USED TO TEST FOR LATE BLIGHT RESISTANCE. For all of the field trials, plants were grown to $\approx 5$ weeks of age then transplanted. In the Ithaca field trials, each plant was spray-inoculated at $\approx 12$ weeks of age with $20 \mathrm{~mL} /$ plant of a 2000 sporangia/mL solution. The Mexico field trials used natural infestation by local isolates. The plants were then surveyed on a periodic basis for percentage defoliation due to late blight using a modified Horsfall-Barratt scale (Horsfall and Barratt, 1945) and data were converted to percent defoliation using Elanco conversion tables (Redman et al., 1969).

The detached leaflet droplet test (Legard et al., 1995) was used in laboratory assays for resistance in plants grown either in the field or in greenhouses with modifications as follows. All leaflet samples were taken at least 6 weeks after germination. Tomato leaflets were collected from the 3-4th leaf from the vine apex to synchronize leaflet age. Each leaflet was placed adaxial surface down on the lids of water agar plates. The abaxial surface of each leaflet was inoculated with two $20-\mu \mathrm{L}$ drops of 40,000 sporangia/ $\mathrm{mL}$, and then covered by water-agar containing petri dish bottom to keep relative humidity near $100 \%$. The plates were incubated upside down at $18{ }^{\circ} \mathrm{C}$ and $16 \mathrm{~h}$ light for 6-7 d. The droplet tests were repeated at least three times. The inoculated leaflets were visually evaluated for the hyphal growth, and then counts of sporangia produced were taken as follows. Leaflets were placed into $5 \mathrm{~mL}$ of sodium acetate and copper sulfate preservation solution followed by $10 \mathrm{~s}$. mixing using a Vortex (Mizubuti and Fry, 1998). Leaflets were removed and sporangia suspensions were held at $4{ }^{\circ} \mathrm{C}$ until sporangia numbers were counted using a 0.2-mm-deep hemocytometer (Hausser Scientific, Horsham, $\mathrm{Pa}$.), and sporangia per leaflet were calculated. The droplet test requires more time/effort to perform than the dipping method (below), but has the advantage of allowing collection of sporangia number data as well as lesion development.

A detached-leaflet dipping test was also developed by modification of the droplet test method. Leaflets were collected for the dipping test in the same manner as for the droplet test. The distal tip half of each leaflet was dipped into 40,000 sporangia/mL sporangia solution then the leaflets were incubated in the same manner as the detached droplet test method. Only visual evaluation data were taken of the leaflets in the dipping test, since sporangia applied per leaflet is not as tightly controlled as in the droplet test. The advantage of dipping method is that it is more rapid to set up than the droplet method and produces results quickly with extremely low rates of escapes.

DATA ANALYSIS. Where the population structure permitted valid use of the statistical tests, segregation data was analyzed using chisquare test with SAS (version 10; SAS Institute, Cary, N.C.).

\section{Results and Discussion}

$\mathrm{BC}_{1} \mathrm{~F}_{1}$ TO PROCESSOR TOMATO POPULATIONS AND THEIR PARENTAL BC $\mathbf{B}_{1} \mathbf{F}_{2}$ FRESH-MARKET ROOTED CUTTINGS. The crosses of the rooted cuttings of R. Gardner's five late blight-resistant [NC215E 
$x$ (NC215E $x$ L3708)] $F_{2}$ selections were used as pollen donors to the three processing hybrid tomato cultivars Heinz 8892 , Rogers 1108 , and Orsetti 3155, resulting in production of 114 $\mathrm{BC}_{1} \mathrm{~F}_{1}$ seeds.

The resulting $\mathrm{BC}_{1} \mathrm{~F}_{1}$ plants were grown in the greenhouse and tested against the $P$. infestans isolate US-17 by the detached leaflet dipping test to examine segregation of the resistance and to identify the most resistant and susceptible plants (Table 1). The plants maintained from the five original cuttings were tested as resistant controls and the three female parental genotypes and NC215E were used as susceptible controls. The dipping test results suggested that two of the five original rooted cuttings (97A45 and 97A47) had lower levels of resistance than the other three rooted cuttings. A subsequent test using the leaflet dipping assay showed that the average sporangia numbers obtained from 97A45 and 97A47 were higher than those for the other three rooted cuttings. The $\mathrm{BC}_{1} \mathrm{~F}_{1}$ populations derived from 97A45 and 97A47 also included very few potentially resistant plants. Therefore, the $\mathrm{BC}_{1} \mathrm{~F}_{1}$ plants derived from 97A 45 and 97A47 were excluded from future work. Plants derived from 97A49 were also eliminated due to greater difficulties in producing seed using this selection as the male parent. Therefore, the subsequent work is all based upon the 34 and $30 \mathrm{BC}_{1} \mathrm{~F}_{1}$ plants from crosses for which 97A46 or 97A48, respectively, was the male parent. Of these $64 \mathrm{BC}_{1} \mathrm{~F}_{1}$ plants, 26 were classified as resistant by the leaflet dipping assay.

Although the sizes of the remaining processor $\mathrm{BC}_{1} \mathrm{~F}_{1}$ populations were too small for a conclusive test of the genetic control of late blight resistance, some observations could be made. Since the processor $\mathrm{BC}_{1} \mathrm{~F}_{1}$ populations derived using either $97 \mathrm{~A} 46$ or 97A48 as the male parent all segregated for resistance, neither 97A46 nor 97A48 was homozygous for the resistance. The processor $\mathrm{BC}_{1} \mathrm{~F}_{1}$ population derived from 97A48 fits a 1:1 segregation ratio expected for control by a single gene; however, the processor $\mathrm{BC}_{1} \mathrm{~F}_{1}$ population derived from 97A46 does not fit a 1:1 segregation ratio, due to a preponderance of susceptible plants (Table 1).

The controls and the $26 \mathrm{BC}_{1} \mathrm{~F}_{1}$ plants that were resistant in the leaflet dipping assay were retested using the $P$. infestans isolate US-17 and the detached leaflet droplet assay to provide an opportunity to collect sporangia number data. The average sporangia numbers of susceptible controls were $275,667 \pm 55,467$ sporangia/ leaflet, in contrast to average sporangial numbers of 6750 and 1500 sporangia/leaflet for the resistant parents 97A46 and 97A48, respectively. The average sporangial numbers obtained from these 26 putative resistant $\mathrm{BC}_{1} \mathrm{~F}_{1}$ plants ranged from 1833 to 67,750 sporangia/leaflet, which are all considerably less than that of the susceptible controls. We ultimately selected six of these resistant processor $\mathrm{BC}_{1} \mathrm{~F}_{1} \mathrm{~s}$, with average sporangial numbers of 1833 to 8833 sporangia/leaflet (Table 1), which are similar to those of the resistant parents 97A46 and 97A48. The six selected $\mathrm{BC}_{1} \mathrm{~F}_{1}$ plants were self pollinated to create $\mathrm{BC}_{1} \mathrm{~F}_{2}$ populations, and were also backcrossed to 'Hypeel 45' and 'Hypeel 303 ' to create $\mathrm{BC}_{2} \mathrm{~F}_{1}$ plants. Self-pollination of the $\mathrm{BC}_{1} \mathrm{~F}_{1}$ produced copious seed, and the crosses resulted in a total of $1212 \mathrm{BC}_{2} \mathrm{~F}_{1}$ seeds.

Processor $\mathbf{B C}_{1} \mathbf{F}_{2}$ Populations. The six $\mathrm{BC}_{1} \mathrm{~F}_{2}$ populations generated from the six $\mathrm{BC}_{1} \mathrm{~F}_{1}$ selections were field grown and lab and field tested for late blight response in Ithaca 1998. Each population included 40 plants, for a total of 120 processor $\mathrm{BC}_{1} \mathrm{~F}_{2}$ plants each derived from 97A46 and 97A48. Leaflets from each plant were collected and tested in the lab against US-17 (970001) with the detached leaflet droplet method and sporangia numbers were counted. After the leaflets were collected for the lab assay, the field was inoculated with US-7 (940486) for a field trial.

The disease response in the Ithaca field test was very severe and very uniform across susceptible controls and spreader rows. All plants of the three processing tomato susceptible controls were more than $90 \%$ defoliated, and $\mathrm{NC} 215 \mathrm{E}$ was $58 \%$ to $84 \%$ defoliated at 15 to $18 \mathrm{~d}$ postinoculation (DPI). The reasons that defoliation of NC215E plants was slower than that of the processing tomatoes might include its larger vine type, later maturity, and/or some other background trait of fresh market tomato that are different from those of processing tomatoes. Processing tomato have far greater concentration of fruit set and greater fruit load per plant size than fresh market lines such as NC215E, and the stress that these traits impose on the processing tomato plants may increase the rate of defoliation of a diseased plant.

The processor $\mathrm{BC}_{1} \mathrm{~F}_{2}$ populations in the field trial clearly segregated for resistance, dividing the populations into plants that were resistant or susceptible to US-7, with the segregation for resistance : susceptibility fitting a 3:1 ratio (Table 2). A very different segregation pattern was obtained when the same plants from these processor $\mathrm{BC}_{1} \mathrm{~F}_{2}$ populations were tested using the detached leaf droplet test with US-17. In this lab assay, the plants were either fully resistant to US-17 or they are not fully resistant. The plants that were not fully resistant could have low levels of resistance or be fully susceptible; it was not possible to reliably assign plants to separate classes of low level resistant vs. fully susceptible. The fully resistant plants were the minority, rather than the majority of the population, and the data do not fit either the $3: 1$ or the $1: 3$ ratio expected for control by one gene. Therefore, the results obtained from the same plants by the two tests using different isolates (US-17 vs. US-7) are clearly different. The US-17 data from processor $\mathrm{BC}_{1} \mathrm{~F}_{2}$ populations fit either the $3: 13$ or $1: 15$ ratios segregation of resistant to susceptible plants expected for control by two epistatic genes (Table 2); however, data from larger populations would be required for a more reliable test of these hypotheses.

Since the same plants were used for the Ithaca field and lab tests, it is possible to simultaneously consider the data from both tests, revealing a relationship between the plants reactions to US-7 and US-17, and separating the plants into three classes (Table 2). The plants fully resistant to US-17 are also fully resistant to US-7, and plants fully susceptible to US-7 are all fully susceptible to US-17. The remaining plants, which are all fully resistant to US-7, were the plants that were not resistant to US-17, but had reduced disease expression compared to their fully susceptible siblings. It appears that plants cannot be resistant to US-17 without also being resistant to US-7, that full susceptibility to US-7 is related to full susceptibility to US-17, and that resistance to US-7 slightly reduces the level of disease response to US-17.

Considering the relative sizes of the three phenotypic classes observed in the $\mathrm{BC}_{1} \mathrm{~F}_{2}$ populations (Table 2), this pattern clearly does not fit the expectation of control by a single incompletely dominant gene, as suggested by Chunwongse et al. (1998, 2002). But rather it suggests that the resistance to US-7 and US-17 involves more than one gene, and that at least some of the genes interact epistatically.

The two gene ratio with the closest fit to the $\mathrm{BC}_{1} \mathrm{~F}_{1}$ data is the $3: 9: 4$ ratio resulting from an epistatic system in which the dominant allele at the epistatic locus conditions resistance to US-7, regardless of the genotype at the hypostatic locus, and in which the homozygous recessive phenotype at the hypostatic locus gives resistance to US-17 only in the presence of the dominant allele at the epistatic locus. Testing the data to this two-gene ratio 
Table 1. Response to P. infestans pathogen isolate US-17 (970001) of susceptible tomato controls and processor tomato populations derived from $97 \mathrm{~A} 46$ and 97A48 after one backcross and two backcrosses to processor parents.

\begin{tabular}{|c|c|c|c|c|c|}
\hline Parent or cutting name & $\begin{array}{l}\text { Type of } \\
\text { parent or } \\
\text { cutting }^{y}\end{array}$ & $\begin{array}{c}\mathrm{BC}_{1} \mathrm{~F}_{1} \\
\text { selection name } \\
\text { (pedigree) }\end{array}$ & $\begin{array}{l}\mathrm{BC}_{1} \mathrm{~F}_{1} \text { test }^{\mathrm{z}} \\
\text { (avg no. } \\
\text { sporangia/ } \\
\text { leaflet) }\end{array}$ & $\begin{array}{c}\mathrm{BC}_{2} \mathrm{~F}_{1} \\
\text { selection name (pedigree) }\end{array}$ & $\begin{array}{l}\mathrm{BC}_{2} \mathrm{~F}_{1} \text { test }^{\mathrm{z}} \\
\text { (avg no. } \\
\text { sporangia/ } \\
\text { leaflet) }\end{array}$ \\
\hline 'NC215E' & $\mathrm{S}$ & & 197,667 & & 399,167 \\
\hline 'Rogers 1108' & S & & 775,000 & & \\
\hline 'Heinze 8892' & S & & 315,000 & & \\
\hline 'Orsetti 3155' & S & & 162,500 & & \\
\hline 'Hypeel 45’' & S & & & & 998,333 \\
\hline 'Hypeel 303' & $\mathrm{S}$ & & & & 261,667 \\
\hline \multirow[t]{5}{*}{$97 \mathrm{~A} 46$} & $\mathrm{R}$ & & 6,750 & & \\
\hline & & $\begin{array}{c}971071-3 \\
(' R o g e r s 1108 ' \text { x 97A46) }\end{array}$ & 8,833 & & \\
\hline & & $\begin{array}{c}971083-7 \\
\text { ('Orsetti 3155'x 97A46) }\end{array}$ & 2,167 & & \\
\hline & & & & $\begin{array}{c}982114-2 \\
\text { ('Hypeel 45' x 971083-7) }\end{array}$ & 14,844 \\
\hline & & & & $\begin{array}{c}982114-4 \\
\text { ('Hypeel 45’ x 971083-7) }\end{array}$ & 7,031 \\
\hline \multirow[t]{5}{*}{ 97A48 } & $\mathrm{R}$ & & 1,500 & & \\
\hline & & $\begin{array}{c}\text { 971079-1 } \\
\text { ('Heinz 8892’ x 97A48) }\end{array}$ & 6,167 & & \\
\hline & & $\begin{array}{c}\text { 971079-10 } \\
\text { ('Heinz 8892' x 97A48) }\end{array}$ & 2,250 & & \\
\hline & & $\begin{array}{c}971085-3 \\
\text { ('Orsetti 3155'x 97A48) }\end{array}$ & 2,000 & & \\
\hline & & & & $\begin{array}{c}982128-39 \\
\text { ('Hypeel 303'x 971079-10) }\end{array}$ & 17,188 \\
\hline
\end{tabular}

zData obtained using detached leaflet droplet method and the pathogen isolate US-17 (970001).

y $\mathrm{S}=$ susceptible control/parent; $\mathrm{R}=$ resistant donor selection.

Table 2. Segregation for resistance to $P$. infestans isolate US-17 and US-7 in $\mathrm{BC}_{1} \mathrm{~F}_{2}$ tomato populations, and tests of the segregation data from the test using each isolate to one-gene (3:1) or two-gene (3:13 and 1:15) ratios, and of combined data from both tests to two-gene (9:4:3) and three-gene $(36: 16: 9)$ ratios.

\begin{tabular}{|c|c|c|c|c|c|c|c|c|c|c|}
\hline Population $^{\mathrm{y}}$ & $\begin{array}{c}\begin{array}{c}\text { No. of } \\
\text { plants }\end{array} \\
\text { S US-17, } \\
\text { R US-7 }\end{array}$ & $\begin{array}{c}\text { No. of } \\
\text { plants } \\
\text { S US-17, } \\
\text { S US-7 }\end{array}$ & $\begin{array}{c}\text { No. of } \\
\text { plants } \\
\text { R US-17, } \\
\text { R US-7 }^{\mathrm{x}}\end{array}$ & $\begin{array}{c}\begin{array}{c}\text { No. of } \\
\text { plants }\end{array} \\
\text { R US-17, } \\
\text { S US-7 } \\
\end{array}$ & $\begin{array}{c}P^{\mathrm{z}} \\
\text { 3R:1S } \\
\text { for } \\
\text { US-7 }\end{array}$ & $\begin{array}{c}P^{\mathrm{z}} \\
\text { 1R:3S } \\
\text { for } \\
\text { US-17 } \\
\end{array}$ & $\begin{array}{c}P^{\mathrm{z}} \\
\text { 3R:13S fo } \\
\text { US-17 }\end{array}$ & $\begin{array}{c}P^{\mathrm{z}} \\
\text { 1R:15S for } \\
\text { US-17 }\end{array}$ & $\begin{array}{c}P^{\mathrm{z}} \\
9: 4: 3 \text { for } \\
\text { S US-17, R US-7: } \\
\text { S US-17, S US-7: } \\
\text { R US-17, R US-7 } \\
\end{array}$ & $\begin{array}{c}P^{\mathrm{z}} \\
\text { 39:16:9 for } \\
\text { S US-17, R US-7: } \\
\text { S US-17, S US-7: } \\
\text { R US-17, R US-7 } \\
\end{array}$ \\
\hline $\begin{array}{l}\text { 97A46-derived } \\
\text { processor } \mathrm{BC}_{1} \mathrm{~F}_{2}\end{array}$ & 72 & 37 & 11 & 0 & 0.140 & 0.000 & 0.007 & 0.187 & 0.020 & 0.158 \\
\hline $\begin{array}{l}\text { 97A48-derived } \\
\text { processor } \mathrm{BC}_{1} \mathrm{~F}_{2}\end{array}$ & 69 & 35 & 16 & 0 & 0.292 & 0.003 & 0.128 & 0.001 & 0.254 & 0.574 \\
\hline Pooled & & & & & 0.074 & 0.000 & 0.003 & 0.001 & 0.007 & 0.138 \\
\hline Homogeneity & & & & & 0.766 & 0.456 & 0.408 & 0.182 & 0.709 & 0.647 \\
\hline
\end{tabular}

Probability of the chi-square test of this ratio.

$\mathrm{yBC}_{1} \mathrm{~F}_{2}$ populations derived either from resistance parent $97 \mathrm{~A} 46$ or $97 \mathrm{~A} 48$, as described in materials.

xData generated by testing the same field-grown plants by both a detached-leaflet droplet test using isolate US-17 (970001) followed by field inoculation of plants with isolate US-7 (940486). For the field test, R US-7 indicates resistant plant, without blight symptoms, S US-7 indicates susceptible plants, with significant defoliation. For the detached leaflet droplet test data: R US-17 = resistant, detected by sporangia numbers less than $\log _{10}$ (avg. sporangia $)=4.50$, which is equivalent to 31,623 sporangia/leaflet. S US-17 = susceptible, detected by sporangia numbers greater than $\log _{10}$ (avg. sporangia $)=4.50$. The average number of sporangia for the susceptible control plants were $\log _{10}($ avg. sporangia $)=5.83$, which is equivalent to 680,724 sporangia/leaflet. 
(3:9:4) gives a poor overall fit to the model since only one of the populations fits this ratio (Table 2). Therefore, a three-gene system was considered.

The closest three gene ratio is the (9:39:16) in which two genes for resistance are dominant and one resistance gene is recessive. In this model, 9/64 of the population would have the genotype A_bb C_ and the phenotype R to US-7, full R to US-17, 16/64 of the population would have the genotype aa $\ldots \ldots$ _ and the phenotype S to US-7, S to US-17, and 39/64 of the population would have the genotype A_bbcc or A_B _ _ and the phenotype $\mathrm{R}$ to US-7 with variable degrees of S to US-17. The data from the $\mathrm{BC}_{1} \mathrm{~F}_{2}$ populations have good fit to this three-gene ratio (Table 2) indicating that the hypothesis might be correct, but this cannot be proved solely by these $\mathrm{BC}_{1} \mathrm{~F}_{2}$ data sets.

Processor $\mathbf{B C}_{2} \mathrm{~F}_{1}$ populations. The $\mathrm{BC}_{2} \mathrm{~F}_{1}$ populations derived from three $\mathrm{BC}_{1} \mathrm{~F}_{1}$ selections (971083-7, 971079-1, and 971079-10) were grown in the greenhouse for late blight lab screens. A total of $173 \mathrm{BC}_{2} \mathrm{~F}_{1}$ plants were tested against US-17 with detached-leaflet dipping method. Susceptible $\mathrm{BC}_{2} \mathrm{~F}_{1}$ plants were identified through four replicates of the dipping test. Again the majority of the plants were susceptible, rather than resistant to US-17 in the lab test. The data sets are homogeneous, but clearly do not fit the 1:1 ratio expected under a one-gene model, or the 1:3 backcross ratio expected for control by two-genes (Table 3 ). However, the populations, grouped by male parent, fit the 1:7 ratio expected for genetic control of resistance by the interaction of three genes (Table 3).

Eighteen putative resistant plants selected out of 173 processor $\mathrm{BC}_{2} \mathrm{~F}_{1}$ plants used in the dipping test were retested with detached leaflet droplet method to compare degree of disease expression with that of the resistant parents. The droplet test was replicated three times and sporangia per leaflet were calculated. Three $\mathrm{BC}_{2} \mathrm{~F}_{1}$ s were ultimately selected, two of which were derived from 97A46 and one derived from 97A48 (Table 1). The average sporangia numbers of these three $\mathrm{BC}_{2} \mathrm{~F}_{1} \mathrm{~S}$ were $13,021 \pm 3,070$ sporangia/leaflet and the average sporangia numbers of the susceptible controls were $553,056 \pm 118,255$ sporangia/leaflet. These three $\mathrm{BC}_{2} \mathrm{~F}_{1} \mathrm{~S}$ were self-pollinated to create $\mathrm{BC}_{2} \mathrm{~F}_{2}$ populations.

Processor $\mathbf{B C}_{1} \mathbf{F}_{3}$ and $\mathbf{B C}_{2} \mathbf{F}_{2}$ Generations. $\mathrm{BC}_{1}$ and $\mathrm{BC}_{2}$ derived populations were lab-tested with US-17 using the dipping test and field-tested with US-7 (940330), along with controls in 1999. The susceptible controls, 'Hypeel 45' and 'Hypeel 303', and the $P h-1$ control, 'New Yorker', were all highly and uniformly susceptible in the field test. The Ph-2 control 'West Virginia 63' initially showed a delay in symptom development but was also, ultimately, very susceptible. The response of the susceptible controls demonstrated that the field trial had excellent disease pressure. All $20 \mathrm{BC}_{1} \mathrm{~F}_{3}$ populations derived from $\mathrm{BC}_{1} \mathrm{~F}_{2}$ plants that were highly susceptible to US-17 in lab tests and to US-7 (940486) in field tests in 1998 were uniformly susceptible in the 1999 field test. Six $B_{1} F_{3}$ populations derived from $B_{1} F_{2}$ plants that were resistant to US-17 in lab tests and to US-7 (940486) in field tests in 1998 were uniformly resistant in the 1999 field test. Two of these resistant $\mathrm{BC}_{1} \mathrm{~F}_{3}$ populations still segregated for indeterminate growth habit, so there were no relationships between indeterminate trait controlled by $S p$ (on the lower arm of chromosome 6) and late blight resistance. Even though pathogenicity of US-7 isolate 940330 was different than the original US-7 isolate used (940486), populations fixed for resistance to US-17 were also fixed for resistant against the 940330 US-7 isolate.

Retesting Processor $\mathrm{BC}_{1} \mathrm{~F}_{2}$ AND $\mathrm{BC}_{1} \mathrm{~F}_{3}$ GENERATIONS IN 2000 TO DETERMINE EFFECTS OF ISOLATE VS. TEST METHOD ON DISEASE SCREEN RESULTS. The question regarding severity of tests used in the lab vs. those in the field test arose from the results of the 1998 and 1999 trials. If the lab test was a more severe screen than the field test, different results might be obtained due to the test used as well as from the differences in the isolate used. Therefore, populations from remnant seed of various generations

Table 3. Segregation in $\mathrm{BC}_{2} \mathrm{~F}_{1}$ tomato populations for late blight response using detached leaflet dipping test with the isolate US-17 (970001), and tests of these data to two-gene (1:3), and three-gene (1:7) backcross ratios.

\begin{tabular}{|c|c|c|c|c|c|c|}
\hline $\mathrm{BC}_{2} \mathrm{~F}_{1}$ population ${ }^{y}$ & R US- $17^{x}$ & S US- $17^{x}$ & Total & df & $\begin{array}{c}P^{z} \\
1 \mathrm{R}: 3 \mathrm{~S}\end{array}$ & $\begin{array}{c}P^{\mathrm{z}} \\
\text { 1R:7S }\end{array}$ \\
\hline \multicolumn{7}{|l|}{ Derived from 97A46 } \\
\hline 'Hypeel 45’ x 971083-7 & 2 & 32 & 34 & 1 & 0.010 & 0.243 \\
\hline 'Hypeel 303’ x 971083-7 & 1 & 31 & 32 & 1 & 0.004 & 0.109 \\
\hline Pooled & 3 & 63 & 66 & 1 & 0.000 & 0.051 \\
\hline Homogeneity & & & & 1 & 0.796 & 0.735 \\
\hline \multicolumn{7}{|l|}{ Derived from 97A48 } \\
\hline 'Hypeel 303' x 971079-1 & 4 & 31 & 35 & 1 & 0.064 & 0.848 \\
\hline 'Hypeel 45' x 971079-10 & 4 & 29 & 33 & 1 & 0.088 & 0.948 \\
\hline 'Hypeel 303’ x 971079-10 & 6 & 33 & 39 & 1 & 0.166 & 0.586 \\
\hline Pooled $^{w}$ & 14 & 93 & 107 & 1 & 0.004 & 0.855 \\
\hline Homogeneity & & & & 2 & 0.915 & 0.859 \\
\hline \multicolumn{7}{|l|}{ Combined population } \\
\hline Pooled & 17 & 156 & 173 & 1 & 0.000 & 0.288 \\
\hline Homogeneity & & & & 4 & 0.767 & 0.535 \\
\hline \multicolumn{7}{|c|}{ 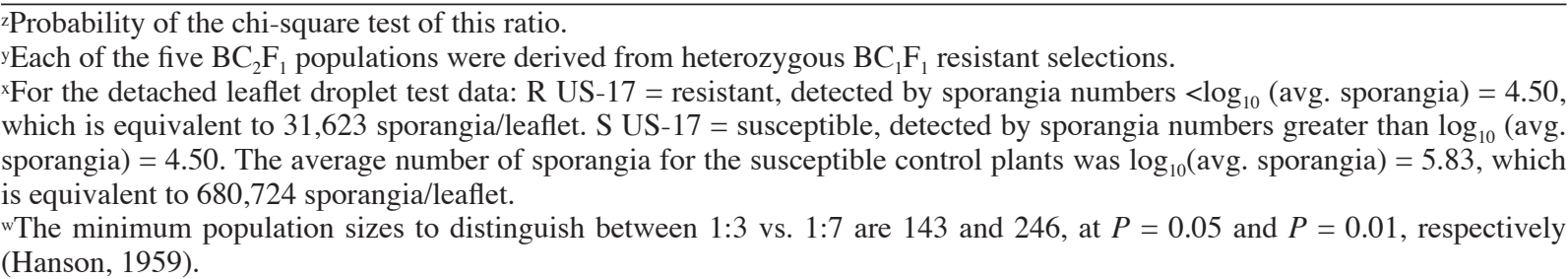 } \\
\hline
\end{tabular}


were field-tested with US-17 and tested by the dipping test with US-7 (940330), testing the same plant populations in a test that was the reverse of the testing in 1998. As controls, eight $\mathrm{BC}_{1} \mathrm{~F}_{3}$ populations that were fixed for resistance to US-7 and US-17 and $12 \mathrm{BC}_{1} \mathrm{~F}_{3}$ populations that were susceptible to both isolates in the 1999 trials were included. The 2000 results on these 20 populations exactly matched the 1999 results, regardless of switching which of the isolates was used in the field vs. the lab assays. Two of the processor $\mathrm{BC}_{1} \mathrm{~F}_{2}$ populations lab-tested in 1998 with US-17 were retested in 2000 field using the same isolate. The results of the tests of these two populations were also similar to those observed in 1998. The segregation of the 1998 lab data fit either a 3:13 or a 1:15 ratio (Table 2); the segregation of the 2000 field data fit either a $3: 13$ or a 1:3 ratio (Table 4 ). Therefore, the method used (lab vs. field), does not appear to have a major impact on the results obtained with the same isolate. Consequently the differences observed in segregation ratios, such as those in the 1998 Ithaca field and lab assays, are more likely due to differences in the isolate used in the tests, not differences in the method used (lab vs. field test). These results support the reliability of the lab test method to predict the performance of resistant plants/lines in field tests against the same isolates. This has important practical ramification, since, to prevent the release of new isolates, breeders cannot use pathogen isolates not already present in the regions of their field tests. Use of the lab test could be advantageous, facilitating the use of multiple isolates in the disease screens for breeding further resistant lines.

Achange in the US-7 isolate used was required when the original stock used (940486) was found to have lost pathogenicity. To test for differences in the pathogenicity of the original and new stock of US-7 isolates, two of the $\mathrm{BC}_{1} \mathrm{~F}_{2}$ populations field-tested in 1998 with US-7 (940486) were retested by detached leaflet dip test in using US-7 (940330). The segregation of these populations tested with US-7 in 1998 fit a 3R:1S ratio, but the 2000 results clearly did not fit this ratio, since the resistant class was smaller than the susceptible class. The 2000 segregation data did not fit $1 \mathrm{R}: 3 \mathrm{~S}$ or $1 \mathrm{R}: 15 \mathrm{~S}$ ratios, but did fit a $3 \mathrm{R}: 13 \mathrm{~S}$ ratio (Table 4), which is similar to the results obtained from US-17 results of same populations in 1998 (Table 2). Therefore, these results suggest that the pathogenicity of 940330 isolate is different from that of 940486 isolate of US-7.

Fresh-MARKet $\mathrm{BC}_{1} \mathrm{~F}_{2}$ and PRocessor $\mathrm{BC}_{2} \mathbf{F}_{3}$ Generations TESTED IN 2000. Dr. Gardner kindly provided us with remnant seeds of the two fresh-market $\mathrm{BC}_{1} \mathrm{~F}_{2}$ populations from which 97A46 and 97A48 had been derived (00A02,00A03, respectively). The results of field-testing these $\mathrm{BC}_{1} \mathrm{~F}_{2}$ populations with US-17 in 2000 support the hypothesis that they would segregate in the same manner as the processor $\mathrm{BC}_{1} \mathrm{~F}_{2}$ and $\mathrm{BC}_{2} \mathrm{~F}_{2}$ populations derived from 97A46 and 97A48 (Table 4). The segregation ratio of the two fresh-market $\mathrm{BC}_{1} \mathrm{~F}_{2}$ populations did not fit the ratio expected for control by single dominant gene, but rather fit the expectation under either a one recessive gene model $(1: 3)$ or an epistatic two-gene model (3:13) (Table 4).

This agreed with the results of our processor $\mathrm{BC}_{1} \mathrm{~F}_{2}$ populations (Table 4). These results, and the lack of fit of the processor $\mathrm{BC}_{2} \mathrm{~F}_{1}$ population segregation ratio to the $1: 1$ ratio for control by a single gene in a backcross $F_{1}$ population (Table 3 ), clearly indicate that the resistance against US-17 is not controlled by single gene. When these fresh-market $\mathrm{BC}_{1} \mathrm{~F}_{2}$ populations were tested with US-7 (940330) using the leaflet-dipping test, the results indicated a lack of fit to either a 1:3 or 3:13 ratios but fit 1:15 ratio (Table 4). Therefore, the results with isolate US-7 (940330) also failed to support the expectations for control by one gene in this population. This also supports the observation of differences in pathogenicity between US-7 (940486) and (940330).

$\mathrm{BC}_{2} \mathrm{~F}_{3}$ seeds collected from $21 \mathrm{BC}_{2} \mathrm{~F}_{2}$ plants selected in 1999 were also grown in 2000, and the resulting $21 \mathrm{BC}_{2} \mathrm{~F}_{3}$ populations were field tested with US-17 and lab tested with US-7 (940330). The results indicated that the $\mathrm{BC}_{2} \mathrm{~F}_{3}$ progeny from 20 of the $\mathrm{BC}_{2} \mathrm{~F}_{2}$ selections were fixed for resistance against both US-17 and US-7 (940330) isolate, and the one remaining $\mathrm{BC}_{2} \mathrm{~F}_{3}$ population segregated for the resistance. Again, making selections based upon both lab and field trials chiefly resulted in selection for plants that were not only resistant to both isolates, but were fixed for the resistance to both isolates. This agrees with the 1998 selections tested in 1999.

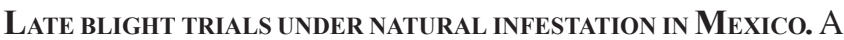
winter/spring late blight trial was performed in 2001 in Los Mochis Mexico under the supervision of I. Stein of Campbell Soup Co. (Camden, N.J.). The trial included 23 late blight-resistant lines (5 $\mathrm{BC}_{1} \mathrm{~F}_{3}$ and $18 \mathrm{BC}_{2} \mathrm{~F}_{3}$ lines), which were supposed to be fixed for late blight resistance as well as six susceptible genotypes as controls. The test rows alternated with susceptible spreader rows, so that all test rows were flanked with spreader rows that provide even disease pressure throughout the entire field. Disease was evenly spread through the spreader rows across the entire field. By mid-Mar. 2001, the plants of the susceptible controls and the alternating spreader rows were $50 \%$ to $70 \%$ defoliated; however, the resistant lines were all $0 \%$ defoliated, except for one $\mathrm{BC}_{2} \mathrm{~F}_{3}$ population that still segregated for the resistance. This population had also segregated in 2000 Ithaca experiment. Disease symptom expression of the susceptible segregants in this $\mathrm{BC}_{2} \mathrm{~F}_{3}$ population was less severe than that of the susceptible processing tomato lines used as a control. This parallels the reduced susceptibility seen in the susceptible segregates in the 1998 field trial in Ithaca. Since natural infestation was used in the Mexico field trial, we do not know the identity of the pathogen isolate(s) present in this trial. However, the results show that the lines fixed for late blight resistance withstand heavy pathogen pressure under conditions very conducive to severe disease.

SynthesIS. L3708-derived late blight resistance, which controls disease caused by a number of $P$. infestans isolates, was transferred to processing tomato lines after two generations of backcrossing. In the process of this transfer, segregation for the resistance shows several points of importance for the further transfer and use of this resistance. The breeding populations supported the importance of the $P h-3$ gene in the resistance from L3708, and all of our breeding populations fixed for the full resistance are homozygous for markers linked to the $P h-3$ gene, as located by Chunwongse et al. (1998). However, segregation for full resistance in our backcross generations does not support the hypothesis that the full resistance is controlled by a single dominant or incomplete dominant gene controlling resistance. Rather, the data indicate that more than one gene is involved in control of this resistance, with the genes interacting in an epistatic manner. The number of genes is not certain, but is likely to be one or hypostatic genes in addition to the epistatic gene, $P h-3$. It is possible that segregation distortion found in early generation interspecific population may affect segregation data and so affect estimates of gene number. In populations derived from cross of tomato and the distant relative, S. pennellii Correll [formerly L. pennellii (Correll) D'Arcy] $80 \%$ and $21 \%$ of markers in $\mathrm{F}_{2} 21 \%$ of $\mathrm{BC}_{1} \mathrm{~F}_{1}$ populations show skewed segregation (de Vincente and Tanksley, 1991, 1993), with the skewed regions located in 16 segments in the 12 chro- 
Table 4. Segregation for late blight response in $\mathrm{BC}_{1} \mathrm{~F}_{2}$ processor tomato populations and $\mathrm{BC}_{1} \mathrm{~F}_{2}$ fresh-market tomato populations ${ }^{\mathrm{z}}$ against isolate US-17 (970001) in a field trial, and isolate US-7 (940330) in a detached leaflet dipping test.

\begin{tabular}{|c|c|c|c|c|c|c|c|c|c|c|}
\hline & df & R US- $17^{\mathrm{x}}$ & S US- $17^{x}$ & $\begin{array}{c}P^{\mathrm{y}} \\
1 \mathrm{R}: 3 \mathrm{~S} \\
\mathrm{US}-17\end{array}$ & $\begin{array}{c}P^{\mathrm{y}} \\
\text { 3R:13S } \\
\text { US-17 } \\
\end{array}$ & R US- $7^{\mathrm{x}}$ & S US- $7^{x}$ & $\begin{array}{c}P^{\mathrm{y}} \\
\text { 1R:3S } \\
\text { US-7 }\end{array}$ & $\begin{array}{c}P^{\mathrm{y}} \\
\text { 3R:13S } \\
\text { US-7 }\end{array}$ & $\begin{array}{c}P^{\mathrm{y}} \\
\text { 1R:15S } \\
\text { US-7 }\end{array}$ \\
\hline \multicolumn{11}{|c|}{ 97A46-derived processor $\mathrm{BC}_{1} \mathrm{~F}_{2}$} \\
\hline 971083-7 self & 1 & 36 & 124 & 0.465 & 0.224 & 22 & 138 & 0.001 & 0.105 & 0.000 \\
\hline $971071-3$ self & 1 & 33 & 127 & 0.201 & 0.543 & 21 & 139 & 0.001 & 0.068 & 0.000 \\
\hline Pooled & 1 & 69 & 251 & 0.156 & 0.167 & 43 & 277 & 0.000 & 0.015 & 0.000 \\
\hline Homogeneity & 1 & & & 0.699 & 0.671 & & & 0.897 & 0.886 & 0.817 \\
\hline \multicolumn{11}{|l|}{ Fresh market $\mathrm{BC}_{1} \mathrm{~F}_{2}$} \\
\hline 00A02 & 1 & 33 & 107 & 0.696 & 0.143 & 13 & 127 & 0.000 & 0.004 & 0.138 \\
\hline 00A03 & 1 & 35 & 125 & 0.361 & 0.311 & 11 & 149 & 0.000 & 0.000 & 0.744 \\
\hline Pooled & 1 & 68 & 232 & 0.351 & 0.082 & 24 & 276 & 0.000 & 0.000 & 0.210 \\
\hline Homogeneity & 1 & & & 0.735 & 0.708 & & & 0.630 & 0.594 & 0.389 \\
\hline \multicolumn{11}{|c|}{ Combined populations } \\
\hline Pooled & 1 & 137 & 483 & 0.095 & 0.033 & 67 & 553 & 0.000 & 0.000 & 0.000 \\
\hline Homogeneity & 3 & & & 0.947 & 0.930 & & & 0.346 & 0.442 & 0.035 \\
\hline
\end{tabular}

${ }^{2} \mathrm{BC}_{1} \mathrm{~F}_{2}$ populations 00A02 and 00A03 were grown from remnant seed of seed lots which also grew the BC $\mathrm{B}_{1} \mathrm{~F}_{2}$ populations from which plants 97A46 and 97A48 were selected. Remnant seed was provided by R. Gardner.

yProbability of the chi-square test of this ratio.

xFor the field test, R US-17 indicates resistant plant, without blight symptoms, S US-17 indicates susceptible plants, with significant defoliation. For the detached leaflet dipping test, R US-7 indicates resistant leaflet, without fungal growth and sporulation, S US-7 indicates susceptible leaflet, with visible fungal growth and sporulation.

wThe minimum population sizes to reliably distinguish between $1: 3$ vs. $3: 13$ are 667 and 1152 , between 1:3 vs. 1:15 are 50 and 86 , between $3: 13$ vs. $1: 15$ are 98 and 170 at $P=0.05$ and $P=0.01$ respectively (Hanson, 1959).

mosomes. However, much less segregation distortion is observed in populations derived from close relatives, such as tomato and S. pimpinellifolium. A survey of a $\mathrm{BC}_{1} \mathrm{~F}_{1}$ population derived from tomato and S. pimpinellifolium, and using 120 markers, revealed skewing for only 10 markers $(8 \%)$, five of which were clustered on chromosome 11 (Grandillo and Tanksley, 1996). The four regions of these 10 skewed markers account for slightly less that $4 \%$ of map distance of the genome. In agreement with that report, no skewing was observed for segregation for known monogenic traits in our breeding populations, such as visually observed segregation for self-pruning $(S p)$, and segregation for resistance genes ( $V e, I 2, M i$, and Pto) using linked PCR markers. Therefore, it is more likely that the deviation from a monogenic ratio observed is due to the action of additional genes, rather than due to segregation distortion.

The segregation results have important implications for breeding efforts to transfer this resistance to additional tomato lines. Use of larger populations and strategies for transfer of more than one gene will be required for further transfer of the full resistance trait. It is also important to note that the segregation ratios observed depended on the pathogen isolate used for the screen. Therefore, to insure that full resistance is transferred to new lines, breeding populations should be tested with a range of isolates, a process facilitated by use of a laboratory based assay. The isolates chosen should represent the full breadth of isolates. Since the segregation data indicates that full resistance across pathogen isolates is not dominant, it is strongly recommended that resistant lines and hybrids be homozygous for the resistance genes.

Since more than one gene is implicated in the resistance, it is not clear whether or not all of the genes involved in the full resistance transferred to our processing tomato lines were derived from L3708. The $P h-3$ gene itself is clearly derived from L3708, since it has been mapped to an S. pimpinellifolium introgression (Chunwongse et al., 1998). It is possible that the other genes in the late blight-resistance complex are also from L3708 or that they were derived from the initial tomato parent, $\mathrm{NC} 215 \mathrm{E}$, since some fully late blight-resistant lines have been produced from pedigrees involving only NC215E and L3708. Examination of our stock of L3708 does not answer this question, since the stock itself was not uniform for resistance. Seven of the eight plants of L3708 tested by leaflet dipping method using US-7(940330) and US-17 (970001) were resistant to US-17, and five of those plants also had resistance to US-7. However, the degree of this resistance to US-7 varied among the plants resistant to both US-17 and US-7. If the NC215E contributed some of the resistance genes transferred to the processing tomato lines, the ultimate source of these additional genes is unclear. All relatively modern tomato lines contain introgressions from wild species as the result of their possessing standard resistance genes (such as Ve or I2), and it is possible that the introgressions carrying those genes, or other regions unknowingly introgressed in the process, may contain some of the hypostatic alleles involved in the full late blight-resistance trait transferred. It may be possible to determine the source of these hypostatic genes as their locations are mapped.

\section{Literature Cited}

Asian Vegetable Research and Development Center. 1994. 1993 Progress report. Asian Veg. Research and Devel. Ctr., Shanhua, Tainan, Taiwan. p. 201-203.

Bonde, R. and E.F. Murphy. 1952. Resistance of certain tomato varieties and crosses to late blight. Maine Agr. Expt. Sta. Bul. 497:5-15.

Caten, C.E. and J.L. Jinks. 1968. Spontaneous variability of single isolates of Phytophthora infestans. I. Cultural variation. Can. J. Bot. 46:329-348. Chunwongse, J., C. Chunwongse, L. Black, and P. Hanson. 1998. Mapping of the Ph-3 gene for late blight from L. pimpinellifolium L3708. Tomato Genetics Coop. Rpt. 48:13-14.

Chunwongse, J., C. Chunwongse, L. Black, and P. Hanson. 2002. Molecular mapping of the $P h-3$ gene for late blight resistance in tomato. J. Hort. Sci. Biotechnol. 773:281-286.

Conover, R.A. and J.M. Walter. 1952. Heritability resistance to late blight of tomato. Phytopathology 42:197-199. 
Conover, R.A. and J.M. Walter. 1953. The occurence of a virulant race of Phytophthora infestans on late blight resistant tomato stocks. Phytopathology 43:344-345.

Davis, R.M., G. Hamilton, W.T. Lanini, and T.H. Spreen. 1996. The importance of pesticides and other pest management practices in U.S. tomato production. USDA, Natl. Agr. Pesticide Impact Assessment Program: Document No. 2-CA-96.

Davis, R.M., G. Hamilton, W.T. Lanini, T.H. Spreen, and C. Osteen. 1998. The Importance of pesticides and other pest management practices in U.S. tomato production. USDA, Natl. Agr. Pesticide Impact Assessment Program, Document No. 1-CA-98.

de Vincente, M.C. and S.D. Tanksley. 1991. Genome-wide reduction in recombination of backcross progeny derived from male versus female gametes in an interspecific cross of tomato. Theor. Appl. Genet. 83:173-178

de Vincente, M.C. and S.D. Tanksley. 1993. QTLanalysis of transgressive segregation in an interspecific tomato cross. Genetics 134:585-596.

Fry, W.E. and S.B. Goodwin. 1997a. Re-emergence of potato and tomato late blight in the United States. Plant Dis. 8112:1349-1357.

Fry, W.E. and S.B. Goodwin. 1997b. Resurgence of the Irish potato famine fungus. Bioscience 476:363-371.

Gallegly, M.E. 1952. Physiologic races of the tomato late blight fungus. Phytopathology 42:461-462.

Gallegly, M.E. 1960. Resistance to the late blight fungus in tomato. Proc. Plant Science Seminar. Campbell Soup Co., Camden, N.J. p. 113-135.

Garelik, G. 2002. Taking the bite out of potato blight. Science 298:1702-1704.

Goodwin, S.B., B.A. Cohen, K.L. Deahl, and W.E. Fry. 1994. Migration from northern Mexico as the probable cause of recent genetic changes in populations of Phytophthora infestans in the United States and Canada. Phytopathology 846:553-558.

Goodwin, S.B., C.D. Smart, R.W. Sandrock, K.L. Deahl,Z.K. Punja, and W.E. Fry. 1998. Genetic charge within populations of Phytophthora infestans in the United States and Canada during 1994 to 1996: Role of migration and recombination. Phytopathology 889:939-949.

Goodwin, S.B., L.S. Sujkowski, and W.E. Fry. 1995. Rapid evolution of pathogenicity within clonal lineages of the potato late blight disease fungus. Phytopathology 856:669-676.

Grandillo, S. and S.D. Tanksley 1996. Genetic analysis of RFLPs, GATA microsatellites and RAPDs in a cross between $L$. esculentum and $L$. pimpinellifolium. Theor. Appl. Genet. 92:957-965.
Hanson, W.D.. 1959. Minimum family size for the planning of genetic experiments. Agron. J. 51:711-715

Horsfall, J.G. and R.W. Barratt. 1945. An improved grading system for measuring plant diseases. Phytopathology 35:655. (Abstr.)

Judelson, H.S. 1997. The genetics and biology of Phytophthora infestans: Modern approaches to a historical challenge. Fungal Genet. Biol. 222:65-76.

Kato, M., E.S. Mizubuti, S.B. Goodwin, and W.E. Fry. 1997. Sensitivity to protectant fungicides and pathogenic fitness of clonal lineages of Phytophthora infestans in the United States. Phytopathology 879:973-978.

Laterrot, H. 1975. Selection for the resistance to Phytophthora infestans in tomato. Annales de l'Amelioration des Plantes Paris 252:129-150.

Laterrot, H. 1994. NILs of tomato except for $P h-2$ gene. Tomato Genetics Coop. Rpt. 44:20-21.

Legard, D.E., T.Y. Lee, and W.E. Fry. 1995. Pathogenic specialization in Phytophthora infestans: Aggressiveness on tomato. Phytopathology 85:1355-1361.

Mizubuti, E.S.G. and W.E. Fry. 1998. Temperature effects on development stages of isolates from three clonal lineages of Phytophthora infestans. Phytopathology 888:837-843.

Peirce, L.C.. 1970. A technique for screening tomato plants for single gene resistance to race O Phytophthora Infestans. Plant Dis. Rpt. 548:681-682.

Peirce, L.C. 1971. Linkage tests with $\mathrm{Ph}$ conditioning resistance to race O, Phytophthora infestans. Tomato Genet. Coop. Rpt. 21:30.

Raposo, R., D.W. Wilks, and W.E. Fry. 1993. Evaluation of potato late blight forecasts modified to include weather forecasts: A simulation analysis. Phytopathology 831:103-108.

Redman, G.E., E.P. King, and I.F.J. Brown.1969. Elanco conversion tables for Barratt-Horsfall rating numbers. Elanco Products Co., Indianapolis.

Richards, M.D. and R.W. Barratt. 1946. A partial survey of genus Lycopersicon for resistance to Phytophthora infestans. Plant Dis. Rptr. 301:16-20.

Turkensteen, L.J. 1973. Partial resistance of tomatoes against Phytophthora infestans, the late blight fungus. PhDThesis. Univ. of Wageningen, The Netherlands.

Umaerus, V. and M. Umaerus. 1994. Inheritance of resistance to late blight, p. 365-401. In: J.E. Bradshaw and G.R.E. Mackay (eds.). Potato genetics. CAB, Wallingford, England. 